\title{
Misconception Of Junior High School Students On Two-Dimentional Figure Materials
}

\author{
Mega Teguh Budiarto ${ }^{1)}$, Siti Khabibah ${ }^{2)}$, Andi Mulawakkan Firdaus ${ }^{3)}$ \\ ${ }_{1,2}$ Universitas Negeri Surabaya, Surabaya, Indonesia \\ ${ }^{3}$ Universitas Muhammadiyah Makassar, Makassar, Indonesia \\ e-mail : ${ }^{1}$ megatbudiarto@unesa.ac.id, ${ }^{2}$ sitikhabibah@unesa.ac.id \\ 3 andi.mulawakkan@unismuh.ac.id
}

\begin{abstract}
This research is a qualitative descriptive study that aims to describe the misconceptions of junior high school students on the material of flat shapes especially geometry of rectangular flat shapes. The subjects of this study were three students who had the most misconceptions from all students in the class. Students' misconceptions in this study were analyzed using a written misconception test with the CRI (Certainty of Response Index) method and continued with interviews to find out the cause of the misconceptions that occurred. Based on the results of data analysis the three subjects showed almost the same misconception. The first misconception experienced by students on rectangular flat figure material lies in the definition of rectangular flat figure. Students' misconceptions in defining lie in a flat shape that has the same side of length, four corners, and two diagonals that form a right angle. This shows that students only choose rectangular regular shapes. In addition, students also experience misconceptions in distinguishing between sides and ribs. The second misconception, lies in the concept of the properties of a rectangular flat shape especially rectangular. Students assume that the rectangle always has an elongated shape without regard to its properties. Furthermore, there is a misconception when showing another wake. Students assume that the ladder is an oblique rectangle. In addition, if a rectangle has a different position or irregular shape then it is not called a rectangle. The cause of the misconception that occurs is the ability to understand the concepts and images given to the problem.
\end{abstract}

Keyword: Misconception, Two-dimentional figure

\section{INTRODUCTION}

Based on the current 2013 curriculum in Indonesia, the learning process is organized with a student centered so that students can actively participate and can build their own understanding of a concept (Firdaus, Juniati, \& Wijayanti, 2019). However, when students try to build their own understanding, there is the possibility of misconceptions. Quoted from Oxford Learner's Pocket Dictionary sixth edition: "Misconception (about) a belief or an idea that is not based on correct information, or that is not understood by people". Misconceptions include understanding and thinking that are not based on accurate information, or are not understood by many people. According to Zembat (2008a) Misconception as a perception or conception that is not compatible with the opinion commonly agreed on by experts on a particular subject. Misconceptions as perceptions or conceptions that are not in accordance with the general opinion agreed by experts on a particular subject. Furthermore Demircioglu (2005) defines misconception as a phenomenon of the occurrence of differences in students' understanding of 
concepts with actual concepts. Someone who has a misconception is very difficult to change his view of certain concepts that experience misconceptions.

From the explanation above, it can be concluded that misconception is a wrong view or understanding of a concept that is owned by someone who is different from the concept that has been agreed upon and is considered correct by experts. Ozkan (2011) revealed that mathematics education has a good and important place in the education process. Because with its own structure mathematics affects scientific studies, technology as a method and methods as a result of economic and social life. Even so, we still face many problems in mathematics education. As long as the problem continues in the lack of learning basic concepts and misunderstandings, it becomes impossible to learn new concepts and it is difficult to understand them (Firdaus, 2019).

One of the mathematical material that requires an understanding of concepts in learning it is the geometry of a rectangular flat figure. Fuji and Jones (2007) revealed that learning geometry of rectangular flat shapes can help students develop the ability of deductive reasoning and proof. Nevertheless, the concept of a rectangle which is one of the material studies of geometry in school mathematics is seen as one of the subjects that is quite difficult because it is abstract. This can lead to misconceptions in students if they do not understand concepts strongly.

The importance of the student's concept of geometry is certainly determined by the student's conception. Students 'conceptions are certainly not as complex as the experts' conceptions, however students 'conceptions can be the same as the experts' simplified conceptions. But if the student's conception is contrary to the conception of the experts, then the student experiences a misconception. If a student experiences a misconception, he will indirectly make mistakes in learning, for example in working on problems.

Based on the description above, an important step should be taken to identify what misconceptions students have and what causes them. Identification of students 'misconceptions is defined as a way to detect student learning that is expected to experience misconceptions of concepts, in this case students' conceptions differ from those of experts. The identification was carried out in this study by using a written diagnostic test with the Certainty of Response Index (CRI) method. Hasan, et.al (1999) revealed that the Certainty of Response Index (CRI) method is a method used to measure the level of student confidence in the material taught by the teacher. Certainly of Response Index (CRI) is a measure of the level of confidence / certainty of the response in answering each question given. Thus it can be understood that misconception is a condition that needs to be addressed because it will inhibit students in understanding other mathematical concepts. Therefore it is necessary to identify related to students' misconceptions on the material of flat shapes especially rectangular flat shapes.

\section{RESEARCH METHOD}

This research is a qualitative descriptive study. The location of the study was carried out in Makassar 21 Public Middle School, especially in class VIII-A. Students are selected only from class VIII because based on the 2013 curriculum the rectangular flat structure material was studied in the previous semester. All students have received rectangular flat class material in class VII semester 2 of 
2019/2020 school year. The test is carried out in class VIII-A odd semester in the academic year 2020/2021.

The determination of the research subject is based on written test results regarding misconceptions. Then 3 subjects were chosen, each of which had a misconception of 18, 16 and 15 questions out of the 20 questions tested. All three study subjects were given a rectangular flat figure construction misconception test. Concepts related to rectangular flat structure material include definitions and properties. Rectangular flat building material used includes squares, rectangles, rhombus, parallelogram, kites and trapezoid.

Student misconception data were obtained using the main instrument and supporting instruments. The main instrument is the researcher himself who interacts directly with the research subject. Supporting instruments are written tests and interview guidelines. The data analysis technique used a written misconception test with the CRI (Certainty of Response Index) method and continued with an interview to find out the cause of the misconception that occurred.

\section{RESULT AND DISCUSSION}

The following are some of the 20 test questions given to students including questions number 1 and 5.

Problem number 1: Consider the following flat figure. Build any flat which is a rectangular flat shape! Why?

(A)

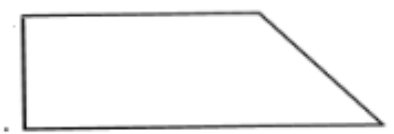

(C)

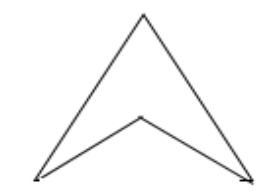

(E)

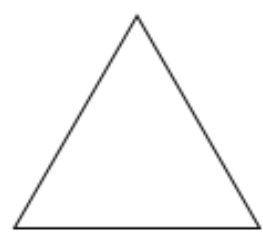

(G)

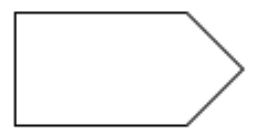

(B)

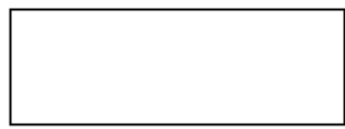

(D)

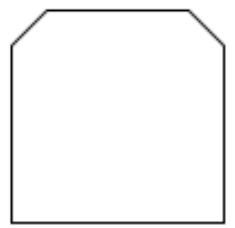

(F)

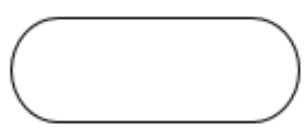

(H)

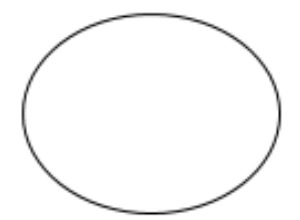


Problem number 2: Among the following pictures, which one is included in the rectangle?

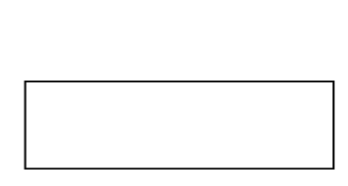

(A)

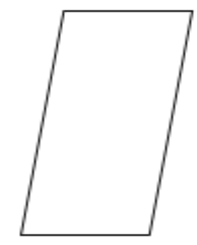

(B)

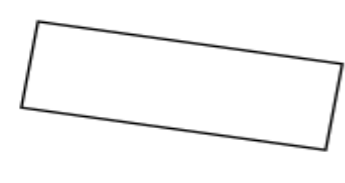

(C)

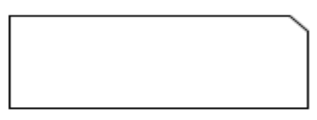

(G)

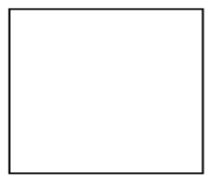

(D)

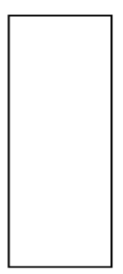

(H)

The misconception test was analyzed using the CRI (Certainty of Response Index) method including CRI scores obtained from each question. In working on the problem of misconception, students also give a CRI value of $0-5$. In this case the student has actually given a self-assessment of the confidence he has in determining the answer to a question. A score of 0 indicates the level of confidence that students have is very low, students answer questions by guessing. So the score of 5 shows the level of student confidence in answering questions is very high. With the CRI method it can find out misconceptions that occur. Information about the results of student work and the causes of subject misconceptions obtained from interviews conducted after the misconception test was done. The results of the analysis and discussion are used to describe the students 'misconceptions and the causes of the students' misconceptions.

The results of students' misconceptions and the causes of misconceptions on rectangular flat figure material.

a. The concept of the definition of a rectangular flat figure

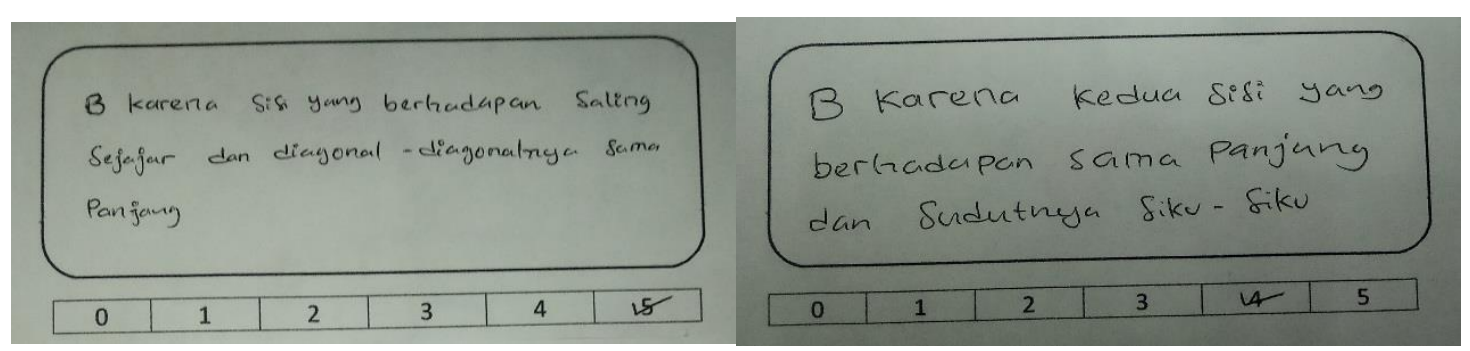

Figure 1. Results of Subject 1 \& 2 Answers in Solving Problem number 1

In this study, it is known that the misconceptions of subjects $1 \& 2$ lie in the definition of a quadrilateral flat figure. The subject considers that the quadrilateral is the same flat shape as the rectangle. So that the other rectangle with a shape that is not the same as the rectangle is not a rectangle. 
In this case the subject experiences a misconception of the concept of a rectangular flat figure definition. This is in line with the results of Farida's (2016) research that many students experience misconceptions on mathematical symbols and terms on rectangular flat material. Because there was an error in the initial understanding of the concept of a quadrilateral. Students assume quadrilateral is only rectangle. They also say that another rectangle with a shape that is not the same as a rectangle is not a rectangle.

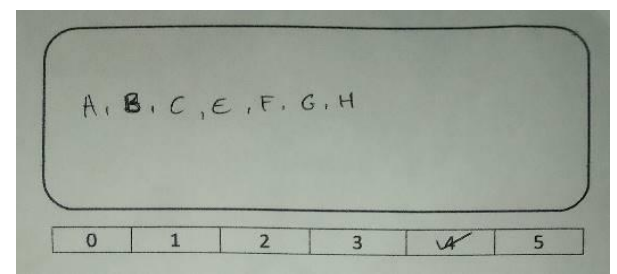

Figure 2. Results of Subject 3's Answers in Solving Problem number 1

In this study, it is known that subject 3's misconception lies in defining the quadrilateral flat figure. The subject only chose to get a uniform rectangular shape. While other rectangles with irregular shapes are considered not quadrilateral, for example as in the matter of drawing part (C) which is a rectangular shape of a concave.

In this case the subject experiences a misconception of the concept of a rectangular flat figure definition. This is in line with the results of Farida's (2016) research that many students experience misconceptions on mathematical symbols and terms on rectangular flat material. Because there was an error in the initial understanding of the concept of a quadrilateral. Students assume quadrilateral is only rectangle. They also say the other quadrilateral with a form that is not the same as the rectangle is not a quadrilateral.

From some of the explanations above, it can be seen that students' misconceptions are on the definition of a rectangular flat figure. Students' misconceptions in defining lie in a flat shape that has the same side of length, four corners, and two diagonals that form a right angle. This can be shown that students can not choose a general rectangle, but only choose rectangles of regular form. In addition students experience misconceptions in distinguishing between sides and ribs. The cause of the misconception that occurs lies in the ability of students to understand the concepts and images given to the problems.

b. The concept of the properties of a rectangle

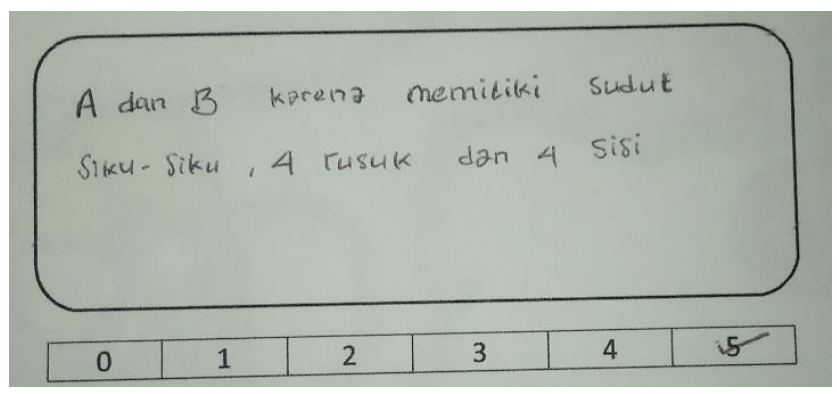




\section{Figure 3. Results of Subject 1's Answers in Solving Problem number 2}

In this research, it is known that subject 1 misconception lies in the properties of rectangles. The subject considers that the rectangle always has the same shape, that is, extends without regard to its properties. In this case the subject experiences a misconception of the concept of rectangular properties. This is in accordance with the results of Ozerem's research (2012) one of the students' misconceptions, namely the lack of understanding of the properties of a rectangular flat figure. Furthermore, the results of Ningrum's research (2016) also showed the same thing, that there was a misconception in the majority of middle school students about the properties of quadrilateral flat figures.

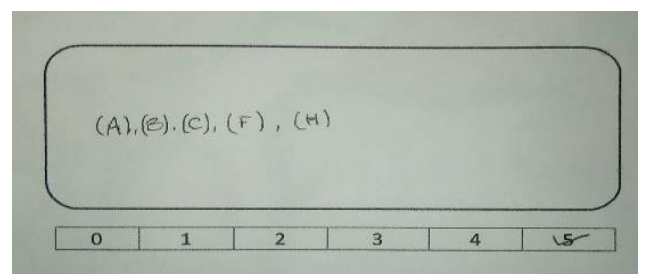

Figure 4. Results of Subject 2's Answers in Solving Problem number 2

In this study, it is known that subject 2's misconception lies in its rectangular properties. Students assume that the ladder is an oblique rectangle. In this case the subject experiences a misconception of the concept of rectangular properties. This is in accordance with the results of Ozerem's research (2012) one of the students' misconceptions, namely the lack of understanding of the properties of a rectangular flat figure. Furthermore, the results of Ningrum's research (2016) also showed the same thing, that there was a misconception in the majority of middle school students about the properties of quadrilateral flat figures.

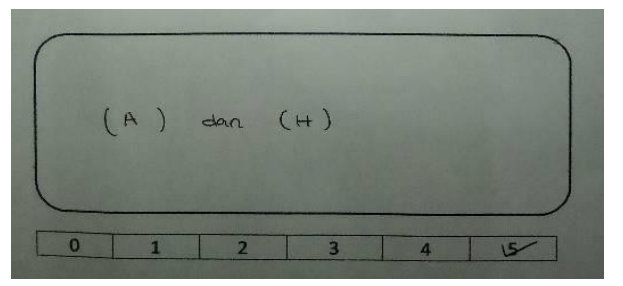

Figure 5. Results of Subject 3's Answers in Solving Problem number 2

In this study, it is known that subject 3's misconception lies in its rectangular properties. The subject considers that the rectangle is only always in an irregular position. In this case the subject experiences a misconception of the concept of rectangular properties. This is in accordance with the results of Ozerem's research (2012) one of the students' misconceptions, namely the lack of understanding of the properties of a rectangular flat figure. Furthermore, the results of Ningrum's research (2016) also showed the same thing, that there was a misconception in the majority of middle school students about the properties of quadrilateral flat figures.

From some of the explanations above, it can be seen the location and causes of misconceptions in students. Misconception in students lies in the concept of the properties of rectangular flat shapes especially rectangles. Students assume that the rectangle always has an elongated shape without regard to its properties. 
Furthermore, there is a misconception when showing another wake. Students assume that the ladder is an oblique rectangle. In addition, if a rectangle has a different position or irregular shape then it is not called a rectangle. The cause of the misconception that occurs is the ability to understand the concepts and images given to the problem.

\section{CONCLUSION}

Based on the results of research and discussion, the conclusions of this study are as follows.

1. The first misconception experienced by students on rectangular flat figure material lies in the definition of rectangular flat figure. Students' misconceptions in defining lie in a flat shape that has the same side of length, four corners, and two diagonals that form a right angle. This shows that students cannot choose common rectangles, but only choose regular rectangular shapes. In addition students experience misconceptions in distinguishing between sides and ribs. The cause of the misconception that occurs lies in the ability of students to understand the concepts and images given to the problems.

2. The second misconception experienced by students on rectangular flat figure material lies in the properties of rectangular flat figure especially rectangular. Misconception in students lies in the concept of the properties of rectangular flat shapes especially rectangles. Students assume that the rectangle always has an elongated shape without regard to its properties. Furthermore, there is a misconception when showing another wake. Students assume that the ladder is an oblique rectangle. In addition, if a rectangle has a different position or irregular shape then it is not called a rectangle. The cause of the misconception that occurs is the ability to understand the concepts and images given to the problem.

\section{REFERENCES}

Demircioglu, G. A. (2005). Conceptual Change Achieved Through A New Teaching Program on Acid and Base. Journal of Chemistry Education Research and Practice, 6(1), 36-51.

Farida, A. (2016). Analisis Miskonsepsi Siswa Terhadap Simbol dan Istilah Matematika Pada Konsep Hubungan Bangun Datar Segiempat Melalui Permainan Dengan Alat Peraga. Prosiding Konferensi Nasional Penelitian Matematika dan Pembelajarannya. Surakarta: Universitas Muhammadiyah Surakarta. 12 Maret.

Firdaus, A. M. (2019). Application of cooperative learning model type Think Pair Share (TPS) on mathematical communication ability. Daya Matematis: Jurnal Inovasi Pendidikan Matematika, 7(1), 59-68.

Firdaus, A. M., Juniati, D., \& Wijayanti, P. (2019, December). Generalization Pattern's Strategy of Junior High School students based on Gender. In Journal of Physics: Conference Series (Vol. 1417, No. 1, p. 012045). IOP Publishing. 
Fuji, T., \& Jones, K. (2017). Learner's Understanding the Definitions and Hierarchical Classification of Quadrilaterals. Research in Mathematics Education, 9(1\&2):3-20

Hasan, S., et.al. (1999). Misconceptions and The Certainty of Response Index (CRI). Journal of Phys. Educ. Vol. V.

Ningrum, R. W. (2016). Miskonsepsi Siswa SMP pada Materi Bangun Datar segiempat dan Alternatif Mengatasinya. Jurnal MathEdunesa, 1(5).

Ozerem, A. (2012). Misconception in Geometry and Suggested Solutions For Seventh Grade Student. International Journal of New Trends in Art, Sport And Science Education, Vol. 7, hal 23-35.

Ozkan, E. M. (2011). Misconception in radical in high school mathematics. Elsevier: Procedia Social Behavioral Science.

Zembat, I.Ö. (2008a). Kavram Yanlg Nedir. M. F. Özmantar, E. Bingölbali, and H. Akkoç (Eds.), Matematiksel Kavram Yanlglar ve Çözüm Önerileri. Ankara: Pegema Yaynck. 